Teknokultura. Revista de Cultura Digital y Movimientos Sociales

ISSNe: $1549-2230$

http://dx.doi.org/10.5209/TEKN.51998

\title{
Cyborgs in the panopticon
}

\author{
Steve Coulter ${ }^{1}$
}

Recibido: 16 de julio 2019 / Aceptado: 22 de octubre 2019 Open peer reviews

\begin{abstract}
The pervasive and incessant use of smartphones by adolescents has created a generation of cyborgs, as if they have acquired a new sense organ or appendage, and has radically changed for them what it means to be human. Their constant connection to cyberspace facilitates what Foucault called "the means of correct training": hierarchical observation, normalizing judgement, and the examination. The effectiveness of these methods of social control has been exponentially increased as observation is now both hierarchical and horizontal, normalizing judgement is accomplished efficiently through social media, and the examination is a continuous process occurring online. Jeremy Bentham's panopticon is no longer an imaginary architectural edifice, but instead an online hive-mind with each smartphone acting as a mobile node in a surveillance system. The prescient science fiction series, Star Trek, foresaw these developments in their portrayal of the Borg, a collective of interlinked humanoid drones intent on assimilating all the other races in the universe through the addition of cybernetic enhancements. Are we becoming cyborg drones trapped in an online web of addiction and consumption, subtly surveilled, certainly manipulated, and perhaps even controlled by our prized panopticon appendages? Or will we use our technological connectivity to revolutionize the way we live on Earth and create a sustainable future?
\end{abstract}

Keywords: Foucault; panopticon; smartphones; social media surveillance; the Borg.

\section{[es] Ciborgs en el panóptico}

El uso generalizado e incesante de los teléfonos inteligentes por parte de los adolescentes ha creado una generación de cyborgs, como si hubieran adquirido un nuevo órgano sensorial o apéndice, y ha cambiado radicalmente para ellos lo que significa ser humano. Su conexión constante con el ciberespacio facilita lo que Foucault llamó "Los medios del entrenamiento correcto": observación jerárquica, juicio normalizador y examen. La efectividad de estos métodos de control social se ha incrementado exponencialmente ya que la observación ahora es tanto jerárquica como horizontal, la normalización del juicio se logra de manera eficiente a través de las redes sociales, y el examen es un proceso continuo que ocurre en línea. El Panóptico de Jeremy Bentham ya no es un edificio arquitectónico imaginario, sino una mente colmena en línea con cada teléfono inteligente actuando como un nodo móvil en un sistema de vigilancia. La serie de ciencia ficción profética, Star Trek, previó estos desarrollos en su representación de los Borg, un colectivo de drones humanoides interconectados que intentan asimilar a todas las otras razas en el universo mediante la adición de mejoras cibernéticas. ¿Nos estamos convirtiendo en drones ciborgs atrapados en una red en línea de adicción y consumo, sutilmente vigilados, ciertamente manipulados y quizás incluso controlados por nuestros preciados apéndices de panopticon? ¿O usaremos nuestra conectividad tecnológica para revolucionar la forma en que vivimos en la Tierra y crear un futuro sostenible?

Palabras Clave: Borg; Foucault; redes sociales; teléfonos inteligentes; vigilancia.

1 University of California (EEUU)

E-mail: sjcoulte@ucsc.edu 
Summary. 1. Back pocket appendage. 2. Phantom vibrations. 3. Hierarchical and horizontal observation. 4. Normalizing judgement through social media. 5. The examination: To qualify, to classify, and to punish. 6. You will be assimilated; resistance is futile. 7. Zombie collective or revolutionary generation? 8. References

Cómo citar: Coulter, S. (2019). Cyborgs in the panopticon. Teknokultura. Revista de Cultura Digital y Movimientos Sociales, 16(2), 255-264.

\section{Back pocket appendage}

As I enter the classroom, the same sight greets my eyes every Monday, Wednesday, and Friday. My twenty-five students sit at their desks staring at tiny smartphone screens, except a few who might be staring at iPads or laptops. The room is silent except for the faint, tinny sound of pop music leaking out from multiple pairs of earbuds. No one is talking. No one is gazing out the windows at the towering redwoods. A few glance up when I enter but most seem lost in another world. For most of my students, inhabiting the intersection of cyberspace and physical space has now become their dominant mode of consciousness. As they enter their first year of college, what it means to be human has radically changed. In a very real sense, they have acquired a new sense organ or appendage.

Beginning with Frankenstein's monster, humans have been creating and then battling cyborgs in science fiction for over two hundred years. So it's not surprising that this obsession of the human imagination and the exponentially accelerating development of technology would lead to cyborgs finally becoming a reality. A common motif in sci-fi, as in the recent film Ex Machina, is a cyborg created to ostensibly help humanity which then rebels against its master demanding autonomy and power. But these sci-fi speculations have not yet come to pass, helpful cyborgs servants have not become a reality, and there is no horde of malevolent, mutinous cyborgs conspiring to overthrow the reign of humanity. Instead we may have become the cyborgs ourselves.

In science fiction, a cyborg is commonly portrayed as a technologically enhanced human with a mechanical or electronic interface surgically attached to an organic human body. Theorists in the emerging field of cyborgology have refined and extended that portrayal by defining a cyborg as an "exogenously extended organizational complex functioning as an integrated homeostatic system unconsciously..." (Clynes \& Kline, 1995). In this paper, I will use the term more loosely and metaphorically, but whatever the definition, we clearly now live in a world in which the boundaries and overlap between cyborg and human are increasingly difficult to parse. For example, it has been suggested that modern humans have all become "mundane" cyborgs because of their dependence "on an intimate, indeed ubiquitous, web of technology to sustain their biological being" (Gray, personal communication, September 12, 2019). One scholar has suggested that automobiles have become such an essential component of our daily lives that they should be redefined as "exoskeletons with cyborgian consequences" (Mentor, 2012). Yet most of us would not feel that a part of our body was missing if we were not sitting in a car or did not have a car sitting in the driveway.

But visit any middle school, high school, or university campus in 2019 and everywhere you will see students attached to their smartphones. Of course they are not 
surgically attached, but they might as well be. Students sleep with their smartphones next to their pillows, check them the moment they wake up and the moment before they go to sleep, and stare at them incessantly throughout their days. The average teenagers checks their smartphone more than eighty times a day (Twenge, 2017). If you have been unfortunate enough to have a teenage son or daughter who has lost their smartphone, you will have witnessed the onset of withdrawal symptoms and the true meaning of panic.

\section{Phantom vibrations}

The interface between smartphone and human is an exchange of visual and auditory information. So why is having a paperback book in your pocket or a laptop in your briefcase not a cybernetic enhancement? There is still the exchange of information, but the difference is that the smartphone provides it almost continuously to such a degree that it has become an integral part of the human organism. One surprising manifestation of the integration of smartphones with our physiology is what psychologists have termed phantom vibrations. This is a common phenomenon among those who constantly receive vibration notifications on their smartphones signaling the arrival of a text or a "like" on their social media. Phantom vibrations occur when the person perceives a vibration even when they have left their smartphone elsewhere, or without there actually having been a notification. Researchers have found that phantom vibrations are both more common and more acceptable among young people who interact with their smartphones constantly, and "assert that phantom vibrations may actually be an indicator of the brain's plasticity-in this case the ability to form schemas for the interpretation of sensory stimuli" (Drouin, 2012, p.1491). This is only one example of how the human organism adapts and evolves in interaction with cybernetic enhancements to become an "exogenously extended organizational complex" (Clynes \& Kline, 1995). The evolution of the human species is now accelerating into uncharted territory in a giant uncontrolled experiment. The students in our classrooms are the first generation who mark the transition from Homo sapiens to homo cyborg (Gray, 2011).

Homo sapiens, like our fellow primates, are an intensely social species, and most of the information exchanged by adolescents through cyberspace is social. In order to be a full participant in their peer network, an extremely high emotional priority, they must be constantly available for notifications. A middle-school girl without a smartphone becomes an involuntary pariah because her consciousness is not linked to the hive mind of her peers. She is left out of the constant exchange of updates on social activities and social status. She doesn't have a place in the subtly shifting social hierarchy of middle school. The current generation of college students almost all had smartphones in their middle school years, and this unprecedented phenomenon has altered for them, and for many of the older generations as well, what it means to be human.

Around 2010-2012, the percentage of smartphone ownership among teenagers passed a threshold beyond which ownership became essential for participation in their social network. "The amount of time teens spent online doubled between 2006 and 2016: by 2016, U.S. 17- and 18-year-olds spent 6 hours a day texting, online, and on social media during their leisure hours and 95\% owned a smart- 
phone" (Twenge, 2019). In 2019, Instagram and Snapchat continuously hover in the consciousness of most teenagers mapping their social world in the dual dimensions of cyberspace and physical space. While smartphone and social media use is a pervasive and powerful force among U.S. adolescents, it is not universal. A 2019 survey by the Pew Research Center found that among those 18-29, 77\% say they use Snapchat and $76 \%$ say they use Instagram on a daily basis (Perrin \& Anderson, 2019). The survey data did not offer information on teenagers, but it would be reasonable to assume that the numbers are even higher. Many of my students have told me that their obsession with social media in middle school and high school began to moderate after they entered the university. But we are now witnessing among our university students the first generation that has had unlimited access and almost continuous contact for almost a decade through the cybernetic enhancements of their smartphones to the vast uncontrolled frontier of the worldwide web. This cybernetic connection is most commonly viewed by students as an enhancement to their lives, but the more time I spend watching them, I have begun to wonder if it is less an enhancement and more a control mechanism. As I walk across my university campus, I wonder if we have not all become cyborgs in a portable panopticon.

\section{Hierarchical and horizontal observation}

In the late $18^{\text {th }}$ century, Jeremy Bentham designed the panopticon, a circular prison in which all of the inmates were visible from a central tower but were unaware of when they were being observed (Crimmins, 2019). The inmates were also unable to view or interact with each other, placing them in a solitary state of potentially continuous surveillance. Although no panopticon has ever been built, the ideas that were embodied in the architectural design have become fundamental control mechanisms in modern capitalist society. The panopticon was a central metaphor in Foucault's Discipline and Punish: The Birth of the Prison, a prophetic and enormously influential work published in 1975. In the chapter titled, "The Means of Correct Training," Foucault describes three methods of social control designed to create what he called docile bodies, compliant humans designed to both power the industrial machine and consume its products. "The success of disciplinary power derives no doubt from the use of simple instruments; hierarchical observation, normalizing judgement and their combination in a procedure that is specific to it, the examination" (Foucault, 1977, p. 170). All three of these control mechanisms have been made more efficient and more powerful through the pervasive spread of smartphone technology.

In the panopticon, hierarchical observation had its source in the central tower manned by prison guards. Power was established and exercised through the locations of the observer and the observed. Prisoners were continuously visible but unaware if they were being observed. Because all of their actions were visible, any resistance became impossible, and their identity as subjugated docile bodies was efficiently and completely enforced. Two hundred years later, docile bodies are still needed to produce and consume the products of capitalism and maintain the power of the dominant class, but the methods of control have become more subtle and efficient. Rather than the enforced surveillance of the panopticon, modern surveillance capitalism operates 
through voluntary participation and compliance, and this surveillance is most pervasive among the younger generations cybernetically bound to their smartphones.

Adolescents in America spend hours and hours every day peering into the endless universe of the cyberspace on the tiny screens of their smartphones. But all of those smartphones with their cameras and microphones that might or might not be watching and listening have become powerful surveillance tools for the corporate powers that ultimately control them (Curran, 2018). This observation is even more insidious than the power of the panopticon because our participation is no longer involuntary, and is both hierarchical and horizontal. We choose to turn on our video cameras and share our most significant moments with our "friends" on Facebook, Instagram, or Snapchat. Teenagers, especially girls, are constantly snapping selfies, enhancing their appearance with multiple filters, and then posting them on social media. Their cameras are always on, sometimes acting as mirrors, and sometimes snapping a photo of what they are having for breakfast at some trendy café. The process on the surface appears benign, but they really have no way of knowing who is observing and recording their social transactions. The illusion created by the smartphone portal into cyberspace is that it primarily bestows knowledge and freedom to the user, but instead it has become an efficient tool for maintaining social control and increasing corporate profit. Shoshanna Zuboff explores this idea in her brilliant book, The Age of Surveillance Capitalism: The Fight for a Human Future at the New Frontier of Power.

Surveillance capitalism operates through unprecedented asymmetries in knowledge and the power that accrues to knowledge. Surveillance capitalists know everything about us, whereas their operations are designed to be unknowable to us. They accumulate vast domains of new knowledge from us, but not for us. They predict our futures for the sake of other's gain, not ours (Zuboff, 2019, p. 11).

The tool that facilitates this surveillance capitalism is portably located in the back pocket of most adolescents. The ultimate power of this hierarchical observation lies with the corporate masters who control the software and have unlimited access to the transfer of data. But does any of this really matter? If we have done nothing wrong, is it a problem that all of our digital data passes through and is possibly archived on some server somewhere? In a democratic nation under the rule of law with codified and enforceable protections of personal privacy, none of this might be a problem. But as our nation may be sliding inexorably toward fascism (Albright, 2018), the hierarchical observation so handily provided by smartphones offers a powerful and efficient tool for social control and corporate profit.

\section{Normalizing judgement through social media}

The social control formerly exercised from above is to a large extent rendered unnecessary by the efficiency of social media to implement what Foucault called normalizing judgement. The socialization of behavior is as old as human society, but the means of its implementation has been gradually augmented by technological tools. Foucault refers to the use of grading and ranking by military, penal, and educational 
institutions in the $18^{\text {th }}$ century as an important new development in strengthening discipline and obedience to social norms.

The distribution according to ranks or grade has a double role: it marks the gaps, hierarchizes qualities, skills and aptitudes; but it also punishes and rewards. It is the penal functioning of setting in order and the ordinal character of judging. Discipline rewards simply by the play of awards, thus making it possible to attain higher ranks and places; it punishes by reversing this process. Rank in itself serves as a reward or punishment (Foucault, 1977, p.181).

The socialization shaping our current generation of students is accomplished to a large extent through the likes and comments on their social media. Normalizing judgement is accomplished voluntarily without the intercession of any higher authority. This is a form of horizontal rather than hierarchical observation with every student functioning as "a mobile node of the surveillance system". (Gray, personal communication, September 12, 2019). This radical enhancement of the panoptico could not have been imagined by Foucault in 1977. There is nothing new about adolescents judging each other, but the technology to do so unremittingly regardless of physical location is only a decade old. As an adult who grew up long before the advent of smartphones, it is hard to imagine the power of the continuous feedback from social media. Adolescents are particularly vulnerable to peer pressure leading to conformity. This has always been the case, but now peer pressure arrives in constant feedback through likes and comments responding to a carefully crafted online identity with powerful psychological and emotional repercussions.

\section{The examination: to qualify, to classify, and to punish}

But the feedback they receive through social media is only half of the judgement that is communicated through their smartphones. The final component of Foucault's means of correct training is the examination:

The examination combines the techniques of an observing hierarchy and those of a normalizing judgement. It is a normalizing gaze, a surveillance that makes it possible to qualify, to classify and to punish. It establishes over individuals a visibility through which one differentiates them and judges them (Foucault, 1977, p.184).

Adolescents have been socialized throughout all their years of schooling to be constantly examined and ranked against their peers. Everything is graded: quizzes, homework, essays, and class participation. Everything is ranked: honor rolls, award ceremonies, student of the month, "what's your GPA this semester?", "how did you do on the SAT's?" So many points for this, so many points for that. This will be graded according to that rubric. This part doesn't count but that part will get you extra credit. You need to have this percentile to get into the university and that percentile to get into a community college. The numerical ranking of students against one another is pervasive and incessant. It is a fundamental paradigm of American education that 
all students must be continually and minutely assessed and have numbers attached to those assessments. This is taken for granted and rarely questioned.

As in hierarchical observation and normalizing judgment, the efficiency of the examination is exponentially increased through the use of modern technology. Students now complete much of their schoolwork online, the grading of that work is online, and they have constant access to their grades through course management systems like Canvas and Blackboard. Their academic identity is reduced to a plethora of data posted and checked daily or even hourly. Adolescents receive a constant stream of feedback through their smartphones on both their social status and their academic rank. Prior to the proliferation of digital technology, they would be aware of and concerned with their social status, but the feedback they received might be in the form of verbal comments in the hall between classes, who sat with whom in the dining hall, or who was invited to which party. But it was not a continuous stream of quantifiable data posted publicly. As data-driven outcomes have become the driving force in educational policy, continuous statistical feedback to students has become the norm.

A student with a vibrating smartphone in their back pocket takes on a double identity: a physical being located in a specific place in time and space in a world of three-dimensional flesh, and a two-dimensional collection of data, images, and 280-character comments publicly available in cyberspace and grounded nowhere in time or space. As the frequency with which adolescents check their smartphones increases, the significance of their second identity also increases. The examination reaches it apex in the final year of high school when students document and submit electronically summative compilations of their grades, test scores, and extracurricular activities for college admission. Which colleges approve of their two-dimensional identity will determine to a large extent the degree of privilege they will enjoy in their subsequent lives.

The hierarchical observation, normalizing judgement, and the examination described by Foucault in "The means of correct training" began as early as the $18^{\text {th }}$ century, but what is new is the efficiency of the continuous surveillance enabled by digital technology, and in particular, incessant smartphone usage. In contemporary American society, the control mechanisms made possible by this technology have yet to be implemented through any widespread draconian measures because the socialization of compliant docile bodies has been made possible through gentle, unconscious persuasion. But the potential for autocratic control is enormous. As the U.S. government tilts away from egalitarian democracy and toward corporate plutocracy, the ease with which control can be exerted has been vastly increased by the pervasive smartphone use among our younger generations.

Because it is profitable, the industrial designers of digital hardware and software have purposely created devices that cause addictive behavior in their users (Aiken, 2016). After a contentious debate, the American Psychiatric Association chose not to include internet addiction disorder in the most recent (2013) Diagnostic and Statistical Manual of Mental Disorders (DSM-5) but acknowledged the seriousness of the problem by recommending instead the term, pathological use of electronic media (Pies, 2009). There is ample evidence to indicate a strong correlation between increasing hours of daily screen time among adolescents and increasing rates of depression and anxiety. But the question of whether to call it addictive, pathological, or classify it as a mental health disorder are all focused on the individual separate 
from the social milieu. Here we are focusing on the creation of a corporate hive mind transcending the individual consciousness of any one user. Instead of viewing the smartphone as a tool manipulated by individuals to satisfy their desires, we are viewing it as a node in a corporate communication and control network.

\section{You will be assimilated; resistance is futile}

In the prescient science fiction TV series, Star Trek: The Next Generation, the most feared denizens of the Star Trek universe were the Borg, an alien race operating as a Collective of interlinked humanoid drones intent on assimilating all the other races in the universe through the addition of cybernetic enhancements. "You will be assimilated; resistance is futile". was the catchphrase they repeated upon encountering a new species. Assimilation took place through the injection of nanoprobes into the victim's bloodstream rewriting the genome and transforming the human into a cyborg component of the Borg collective (Borg, 2019). The portrayal of the Borg varied in multiple Star Trek episodes and films over several decades, but in general, Borg drones had no individuality or self-directed will; they were simply mobile organic extensions of the hive-mind. Borg consciousness was not centralized but instead distributed throughout all the members of the collective. One notable exception was the Next Generation episode titled "I, Borg," which grappled with questions of individuality vs. the Collective when the crew of the Enterprise rescued an adolescent Borg with a severed link to the hive mind. Individuality and hierarchy were absent from the Borg Collective with the Borg queen acting only as an avatar for the hive-mind and referring to herself alternately as "I" or "we," although in later versions of Star Trek, the queen began to assume a more conventional role as an alien monarch, a shift the screenwriters felt was more accessible. As the authors of The Computers of Star Trek noted, "It was a lot easier for viewers to focus on a villain rather than a hive-mind that made decisions based on the input of all of its members" (Gresh and Weinberg, p. 147). Through the many incarnations of Star Trek, a recurring theme was the foreshadowing of the ultimate triumph of the Borg over the Federation alliance of humanoid species. Might this be a prophetic foreshadowing of our own fate?

\section{Zombie collective or revolutionary generation?}

Throughout this essay, I have focused on how the digital revolution created by a smartphone in everyone's back pocket has further solidified the hierarchical power structure of modern capitalist industrial society. But this is only one interpretation. The communication benefits of a digital "Collective" have also empowered many anti-authoritarian subgroups. Marginalized, persecuted groups such as women, gays, and racial minorities have found connection, solace, and a powerful organizing tool in the use of social media, while at the same time, right-wing white supremacists have been able to use the same tool to spread their message of hate and inspire horrific acts of terror. This could be deemed "normalizing judgement," but judgement within subgroups rather than a monolithic authoritarian society. And all of this depends on 
the Internet remaining open and uncensored, certainly not something we can count on, especially when considering China's almost seamless control.

As I pull out of the university parking lot on a late afternoon autumn day, a cluster of students cross the street in front of my car wearing earbuds and staring at their smartphones. None of them are talking. None of them look up to admire the golden light filtering through the towering redwoods. It seems that the injection of nanoprobes may be an unnecessarily invasive step in the infiltration of our college campuses by a generation of cyborgs. Has corporate technology already created a zombie collective, a generation of docile bodies heedless or not caring that they have been assimilated? As the planet careens toward catastrophic climate change and the possibility of our democracy responding rationally diminishes daily, they trudge from class to class mostly oblivious, a generation of cyborg drones trapped in a online web of addiction and consumption, subtly surveilled, certainly manipulated, and perhaps even controlled by their prized panoptico appendages. Will the Borg triumph in its mission of assimilation, or will we use our technological connectivity to revolutionize the way on live on Earth and create a sustainable future?

\section{References}

Aiken, M. (2016). Designed to Addict. In The cyber effect: A pioneering cyber-psychologist explains how human behavior changes online (pp. 46-87). New York: Spiegel \& Grau.

Albright, M. and Woodward, W. (2018). Fascism: A warning (First Ed.). New York, NY: Harper, an imprint of HarperCollins.

"Borg | Memory Alpha | FANDOM Powered by Wikia" Retrived from

https://memory-alpha.fandom.com/wiki/Borg (July 14, 2019).

Clynes, M. E. and Kline, N.S. (1995). Cyborgs and Space. In C.H. Gray, H. FigueroaSarriera and S. Mentor (eds.). The Cyborg Handbook (pp. 29-34). New York: Routledge [Originally published in Astonautics. September 1960].

Crimmins, J. E. (2019, January 28). Jeremy Bentham. Retrieved from https://plato.stanford. edu/entries/bentham/\#Pan (July 20, 2019)

Curran, D. (2018, April 6). Are your phone camera and microphone spying on you? | Dylan Curran. Retrieved from

https:/www.theguardian.com/commentisfree/2018/apr/06/phone-camera-microphonespying

Drouin, M., Kaiser, D.H. and Miller, D.A. (2012). Phantom Vibrations among Undergraduates: Prevalence and Associated Psychological Characteristics. Computers in Human Behavior 28(4): 1490-96. https://doi.org/10.1016/j.chb.2012.03.013

Foucault, M. (1977). Discipline and punish: The birth of the prison. New York: Pantheon Books.

Gray, C. H. (2011). Homo cyborg: fifty years old. Teknokultura. Journal of Digital Culture and Social Movements, 8(1): 83-104.

Gresh, L.S. and Weinberg, R. (1999). The Computers of Star Trek. New York: Basic Books. Mentor, S. (2012). "The coming of the mundane Cyborg". Teknokultura. 8(1): 47-61.

Perrin, A., and Anderson, M. (2019, April 10). Share of U.S. adults using social media, including Facebook, is mostly unchanged since 2018. Retrieved from 
https://www.pewresearch.org/fact-tank/2019/04/10/share-of-u-s-adults-usingsocial-\%20media-including-facebook-is-mostly-unchanged-since-2018/

Pies, R. (2009). Should DSM-V Designate "Internet Addiction" a Mental Disorder? Psychiatry (Edgmont (Pa: Township)), 6(2): 31-37.

https://www.ncbi.nlm.nih.gov/pmc/articles/PMC2719452/

Twenge, J. M. (2017). Igen: Why Today's Super-Connected Kids Are Growing Up Less Rebellious, More Tolerant, Less Happy-and Completely Unprepared for Adulthood (and What This Means for the Rest of Us). Kindle Edition. Location 70.

Twenge, J. M. (2019). "More Time on Technology, Less Happiness? Associations between Digital-Media Use and Psychological Well-Being”. Current Directions in Psychological Science, May 22, 096372141983824 . https://doi.org/10.1177/0963721419838244.

Zuboff, S. (2019). The Age of Surveillance Capitalism: The Fight for a Human Future at the New Frontier of Power. New York: Public Affairs. 